\title{
Drying Characteristics of Carrot and Green Pumpkin Slices in Waste Heat Dryer
}

\author{
Gwi Hyun Lee* \\ Department of Biosystems Engineering, Kangwon National University, Chuncheon, Korea \\ Received: January $29^{\text {th }}, 2012$; Revised: February 21 ${ }^{\text {th }}, 2012$; Accepted: February $29^{\text {th }}, 2012$
}

\section{Abstract}

Purpose: Drying characteristics of the sliced carrot and green pumpkin were investigated by using the waste heat dryer. Methods: The effects of drying temperature $(T)$ and slice thickness affecting drying time were analyzed. Mathematical models for the drying curves were determined with statistical analysis of drying data. Effective diffusivity was determined for the slices of carrot and green pumpkin under various drying conditions. Results: Drying time was reduced at the drying conditions of thinner slice and higher drying temperature. Moisture ratio $(M R)$ according to drying time $(t)$ was well presented as an exponential function at all of drying conditions for the slices of carrot and green pumpkin with the determination coefficient $\left(r^{2}\right)$ of $>0.99$. The values of effective diffusivity $\left(D_{f f}\right)$ of the slices for carrot and green pumpkin were increased with increasing the drying temperature. The relationship between $\operatorname{Ln}\left(D_{f f}\right)$ and $1 / T$ was linear with the determination coefficient $\left(r^{2}\right)$ of $>0.97$. Conclusions: Drying model was well established as an exponential function at all of drying conditions for drying samples.

Keywords: Carbonizing furnace, Drying characteristics, Drying model, Drying, Waste heat dryer

\section{Introduction}

Drying is one of the ways used for a long time to prevent the decay and deterioration of agricultural products by the removal of moisture. Various agricultural products such as grains, vegetables, and fruits are usually dried for long time storage and for future utilization as foods. Carrot and green pumpkin are dried in the form of slice for preservation and for the use as food material even though they can be used in the fresh state. Recently, some of dried carrot and pumpkin slices are imported from China. Solar drying is the traditional method, which produces a product with desirable properties in color, flavor, and texture. However, it has many disadvantages, such as long drying time, exposure to contamination from dust and insects, etc.

\footnotetext{
*Comesponding author: Gwi Hyun Lee

Tel: +82-33-250-6495; Fax: +82-33-255-6406

E-mail: ghlee@kangwon.ac.kr
}

It is known that drying method affects greatly the quality of product. Therefore, many kinds of drying method such as far-infrared drying (Abe and Afzal, 1997; Fu and Lien, 1998; Afzal and Abe, 2000), microwave drying (Adu and Otten, 1996), etc. have been applied to improve the quality of dried products. However, hot-air drying is widely used in the food processing industry until now. Drying involves the vaporization of moisture within the product by heat and its subsequent evaporation from the product (Ekechukwu, 1999). The usual drying method of agricultural products is the thin-layer drying with hot air. Drying of agricultural products is generally performed in the range of $50^{\circ} \mathrm{C}$ to $70^{\circ} \mathrm{C}$ to minimize changes in color and flavor qualities. Drying of agricultural products is a unit operation involving simultaneous heat and mass transfer, which stabilizes the product by lowering its moisture content and water activity.

A lot of research has been reported about thin-layer drying characteristics of agricultural products such as soybeans (Osborn et al., 1991), corn (Weres and Jayas, 
1994), garlic slices (Madamba et al., 1996), brined onion slices (Sarsavadia et al., 1999), paprika (Ramesh et al., 2001), potato slices (Youcef-Ali et al., 2001), and red pepper (Doymaz and Pala, 2002). The process of thinlayer drying of agricultural products has been described mathematically with several models (Henderson and Pabis, 1961; Chinnan, 1984; Misra and Brooker, 1980; Lee et al., 2004; Kim and Han, 2009).

The objectives of this study were to investigate the thin-layer drying characteristics of the slices of carrot and green pumpkin as influenced by drying temperature and slice thickness and to find suitable mathematical models for the drying curves.

\section{Materials and Methods}

\section{Drying model}

The drying phenomenon of biological materials is controlled by the mechanism of moisture diffusion during the falling rate period. Fick's second law of diffusion can be used for describing the rate of moisture movement during drying for homogeneous materials, in which the heterogeneity of the material is taken into account by using effective diffusivity. The diffusion equation is as follows:

$$
\frac{\partial M}{\partial t}=D_{e f f}\left(\frac{\partial^{2} M}{\partial r^{2}}+\frac{C}{r} \frac{\partial M}{\partial r}\right)
$$

Where, $M$ is the average moisture content (\%, d.b.), $\mathrm{t}$ is the drying time (hr), $D_{e f f}$ is the effective diffusivity $\left.\mathrm{m}^{2} / \mathrm{hr}\right), r$ is the distance from center (m), and $C$ is the constant according to shape of drying material. Initial and boundary conditions of equation 1 are as follows:

$$
\begin{aligned}
& M(r, 0)=M_{o} \\
& M\left(r_{o}, t\right)=M_{e}
\end{aligned}
$$

Where, $r_{o}$ is the radius for infinite cylinder and sphere and the half thickness for infinite slab (m), $M_{o}$ is the initial moisture content (\%, d.b.), $M_{e}$ is the equilibrium moisture content $(\%$, d.b.). With the assumptions of moisture migration by diffusion, negligible shrinkage, and constant diffusion coefficients and temperature, analytical solution of Fick's equation for a semi-infinite slab is as follows (Crank, 1975):

$$
\begin{aligned}
M R & =\frac{\left(M-M_{c}\right)}{\left(M_{o}-M_{e}\right)} \\
& =\frac{8}{\pi^{2}} \sum_{n=0}^{\infty} \frac{1}{(2 n+1)^{2}} \exp \left[-\frac{(2 n+1)^{2} \pi^{2}}{4 L^{2}} D_{e f f} t\right]
\end{aligned}
$$

Where, $M R$ is the dimensionless moisture ratio and $L$ is the half thickness of sample (m). For the high value of drying time, equation 2 rapidly converges and terms with $\mathrm{n}>1$ can be neglected and thus simplified as follows (Henderson and Perry, 1976):

$$
M R=A \exp (-K t)
$$

Where, $K$ is the drying constant and $A$ is the general constant which is determined according to the shape of drying material. The values of $A$ and $K$ can be obtained through the thin-layer drying experiment. This theoretical model has been used to describe the drying process of many agricultural products (Pabis and Henderson, 1961; Henderson and Henderson, 1968; Young and Whitaker, 1971; Parry, 1985; Tang and Sokhansanj, 1993; Lee and Hsieh, 2008). Drying constant ( $K$ ) of equation 3 can be related with the effective diffusivity $\left(D_{e f f}\right)$ of equation 2 as follows (Lee et al., 2004):

$$
K=\frac{D_{e f f} \pi^{2}}{4 L^{2}}
$$

The effect of drying temperature on effective diffusivity $\left(D_{e f f}\right)$ is also presented as the following Arrhenius-type equation (Coumans, 2000; Duc et al., 2008; Simal et al., 2000):

$$
D_{\text {eff }}=D_{o} \exp \left(-\frac{E_{a}}{R T}\right)
$$

Where, $D_{o}$ is a constant equivalent to the effective diffusivity $\left(\mathrm{m}^{2} / \mathrm{hr}\right), E_{a}$ is the activation energy (J/mol), $R$ is the gas constant $(8.314 \mathrm{~J} / \mathrm{mol} \cdot \mathrm{K})$, and $T$ is the temperature of air $(\mathrm{K})$.

\section{Dryer}

In this study, the hot-air dryer using the waste heat of carbonizing furnace was used in drying experiment. XL-pipe was buried along the round of the ceiling wall of carbonizing furnace (Figure 1). Heat produced by carbonizing process is transferred into the fluid, which is 


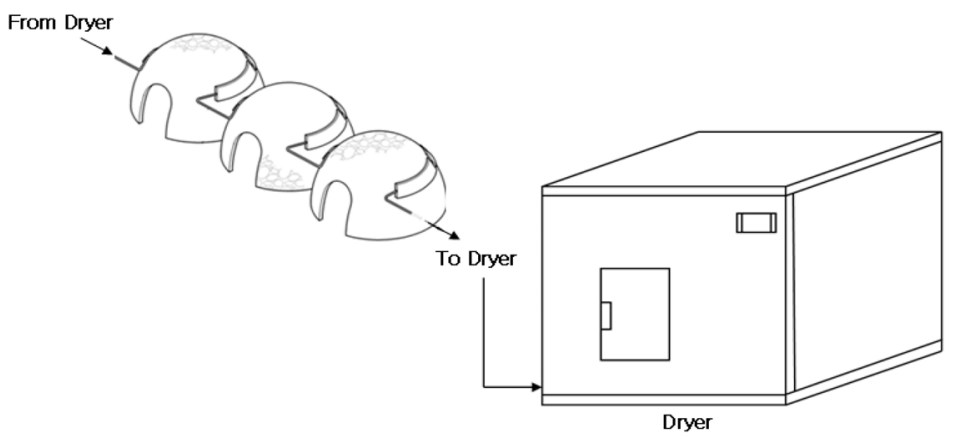

Figure 1. Systemic diagram for the dryer using waste heat of carbonizing furnace.

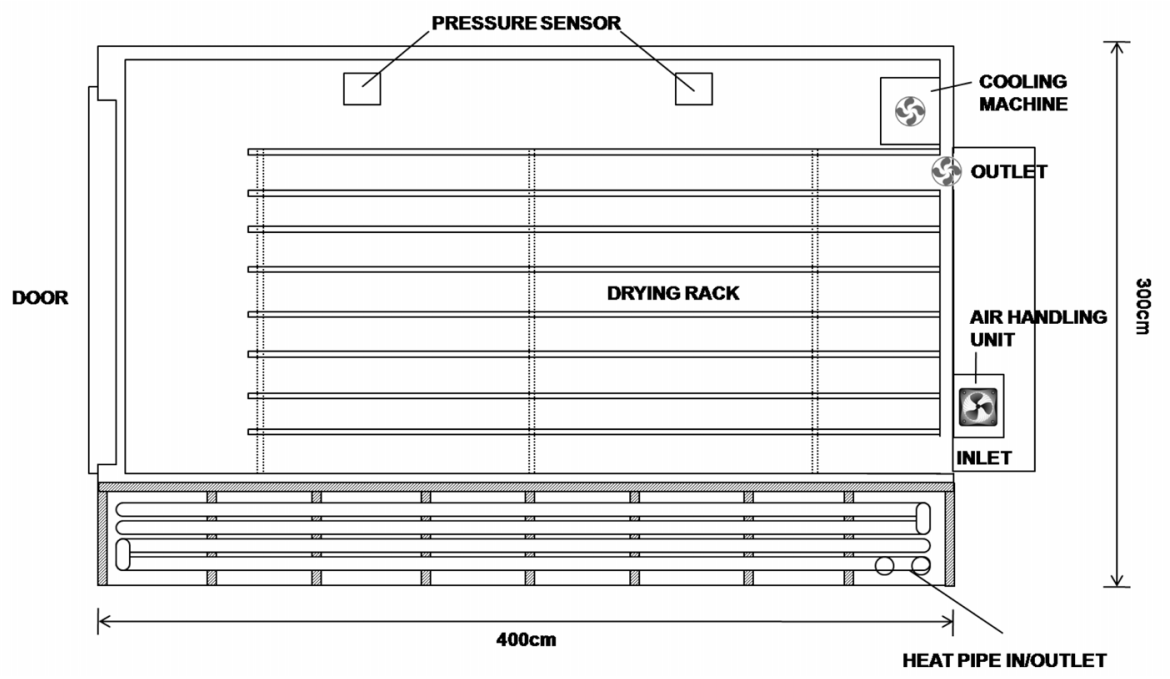

Figure 2. Detailed structure of waste heat dryer.

circulating inside the XL-pipe of carbonizing furnace. Then, heated fluid is forced into the copper pipe installed at the bottom of drying chamber as the heat exchanger (Figure 2). Air around the copper pipe is heated and goes through inside the drying chamber by fan. Dryer has several layers of drying racks inside the drying chamber. Pressure sensor is installed for the automatic opening of ventilating hole when the pressure inside drying chamber is increased by moisture evaporation of drying materials. Moreover, the waste heat dryer is equipped with the cooling units for using as the storage chamber of agricultural products as well as dryer.

\section{Materials and experimental methods}

Carrot (Daucus carota L.) and green pumpkin (Cucurbita spp.) were obtained at the market in October, 2010 and then stored in a storage chamber set at $4{ }^{\circ} \mathrm{C}$ for several days prior to drying tests. For the drying experiment, carrot and green pumpkin were removed from the storage chamber. Then they were washed, maintained at the room temperature for 30 minutes after removal of the moisture on the wet surface, and sliced for drying test. Three samples of $100 \mathrm{~g}$ for each experimental material were used to determine the initial moisture content in an air oven (VS-1202D3, Vision Scientific Co., Korea) at $80^{\circ} \mathrm{C}$ for 48 hours. After drying, the sample masses were measured after cooling in a desiccator with silica gel for 30 min. Initial moisture content of each experimental material was calculated on the dry basis. Airflow rate set at a level was measured at the top, middle, and bottom inside the drying chamber with using an anemometer (Model 24-6111, Kanomax, Inc., Japan). Averaged airflow rate of three measurements was $0.8 \mathrm{~m} / \mathrm{s}$. Relative humidity (RH) inside the drier was measured by data logger with moisture sensor (Model LI-1400, LI-COR Inc., USA). Relative humidity was $7.2 \%, 4 \%, 2,5 \%$ for each drying temperature of $50{ }^{\circ} \mathrm{C}, 60^{\circ} \mathrm{C}$, and $70^{\circ} \mathrm{C}$. Carrot and green pumpkin were sliced into transverse sections of 1 , 
2 , and $3 \mathrm{~mm}$ thickness. Drying tests were replicated three times for each of three drying temperatures $\left(50^{\circ} \mathrm{C}, 60^{\circ} \mathrm{C}\right.$, and $70^{\circ} \mathrm{C}$ ) with each sliced sample of three thicknesses. Samples were weighed on an electronic balance (Model FA-3000KV, A\&D Co., Japan) with a sensitivity of $0.001 \mathrm{~g}$ at constant time intervals during drying experiment. To complete drying and attain equilibrium, the drying test was terminated when the change of sample mass was less than $0.01 \mathrm{~g}$. After drying test, equilibrium moisture content $\left(M_{e}\right)$ of the sample was determined by the same procedure used for measurement of initial moisture content. Moisture content of sample during drying period was calculated at each drying time of constant time interval and presented as the moisture ratio (MR). Average values of each drying test were used for the drying curves of three slice thicknesses of each sample for three drying temperature. Drying data were evaluated by a nonlinear regression program (SigmaPlot 2000, SPSS Inc., USA).

\section{Results and Discussion}

The initial moisture contents $\left(M_{o}\right)$ of carrot and green pumpkin were $91.0 \%$ (w.b.) and $93.7 \%$ (w.b.), respectively.
Table 1 shows total drying time, half drying time, and equilibrium moisture content $\left(M_{e}\right)$ for each sample of three thicknesses under different drying temperature. Equilibrium moisture content was varied from $12.8 \%$ to $3.7 \%$ for carrot and from $8.6 \%$ to $4.7 \%$ for green pumpkin depending on drying temperature and slice thickness.

Total drying time and half drying time were decreased greatly with increasing the drying temperature. The half drying time of $3 \mathrm{~mm}$ thickness for each drying temperature of $50^{\circ} \mathrm{C}, 60^{\circ} \mathrm{C}$, and $70^{\circ} \mathrm{C}$ was $102 \mathrm{~min}, 84 \mathrm{~min}, 72 \mathrm{~min}$ for carrot and $114 \mathrm{~min}, 60 \mathrm{~min}, 54 \mathrm{~min}$ for green pumpkin. Total drying time and half drying time were also decreased with decreasing the slice thickness under same drying temperature.

Figures 3 and 4 show the typical drying curves of moisture ratio $(M R)$ versus drying time $(t)$ for carrot and green pumpkin sliced to 1,2 , and $3 \mathrm{~mm}$ thickness at drying temperature of $50^{\circ} \mathrm{C}, 60^{\circ} \mathrm{C}$, and $70^{\circ} \mathrm{C}$. As expected, the results showed that drying time decreased greatly as drying temperature increased and slice thickness decreased. The drying rate can be obtained from the slop of the drying curve. The slop of drying curve was increased with increasing drying temperature and decreasing slice thickness.

Table 1. Drying and half drying time of agricultural products

\begin{tabular}{|c|c|c|c|c|c|}
\hline $\begin{array}{l}\text { Experimental } \\
\text { material }\end{array}$ & $\begin{array}{l}\text { Drying temperature } \\
\qquad\left({ }^{\circ} \mathrm{C}\right)\end{array}$ & $\begin{array}{l}\text { Thickness } \\
\text { (mm) }\end{array}$ & $\begin{array}{c}\text { EMC } \\
\text { (\% d.b.) }\end{array}$ & $\begin{array}{l}\text { Half drying time } \\
(M R=0.5)(\mathrm{min})\end{array}$ & $\begin{array}{l}\text { Drying time } \\
\quad(\mathrm{hr})\end{array}$ \\
\hline \multirow{9}{*}{ Carrot } & \multirow{3}{*}{50} & 1 & 5.6 & 42 & 4 \\
\hline & & 2 & 8.2 & 54 & 5 \\
\hline & & 3 & 12.8 & 102 & 7 \\
\hline & \multirow{3}{*}{60} & 1 & 3.8 & 42 & 4 \\
\hline & & 2 & 5.0 & 50 & 5 \\
\hline & & 3 & 6.6 & 84 & 7 \\
\hline & \multirow{3}{*}{70} & 1 & 3.7 & 36 & 4 \\
\hline & & 2 & 4.9 & 42 & 5 \\
\hline & & 3 & 6.4 & 72 & 6 \\
\hline \multirow{9}{*}{ Green Pumpkin } & \multirow{3}{*}{50} & 1 & 5.4 & 50 & 6 \\
\hline & & 2 & 7.1 & 84 & 8 \\
\hline & & 3 & 8.6 & 114 & 9 \\
\hline & \multirow{3}{*}{60} & 1 & 4.9 & 42 & 4 \\
\hline & & 2 & 5.6 & 48 & 5 \\
\hline & & 3 & 5.9 & 60 & 6 \\
\hline & \multirow{3}{*}{70} & 1 & 4.7 & 24 & 3 \\
\hline & & 2 & 5.8 & 42 & 4 \\
\hline & & 3 & 5.8 & 54 & 5 \\
\hline
\end{tabular}


Theoretical model (eq. 3) was fited to the drying data describing the drying curves for carrot and green pumpkin slices of 1, 2, and $3 \mathrm{~mm}$ thickness at drying temperature of $50^{\circ} \mathrm{C}, 60^{\circ} \mathrm{C}$, and $70^{\circ} \mathrm{C}$. Calculated moisture ratio and drying time were used in fitting the model. Table 2 presents the exponential relationship between moisture ratio and drying time from non-linear regression analysis. Coefficients of determination $\left(r^{2}\right)$ which is the primary criteria to decide the validation of the model for drying curve were $>0.99$. For each drying temperature of $50^{\circ} \mathrm{C}, 60^{\circ} \mathrm{C}$, and 7 $0^{\circ} \mathrm{C}$, the value of $K$ was decreased and the value of $A$ was increased with increasing the slice thickness for both carrot and green pumpkin. Also, the value of $K$ was increased and the value of $A$ was decreased with increasing
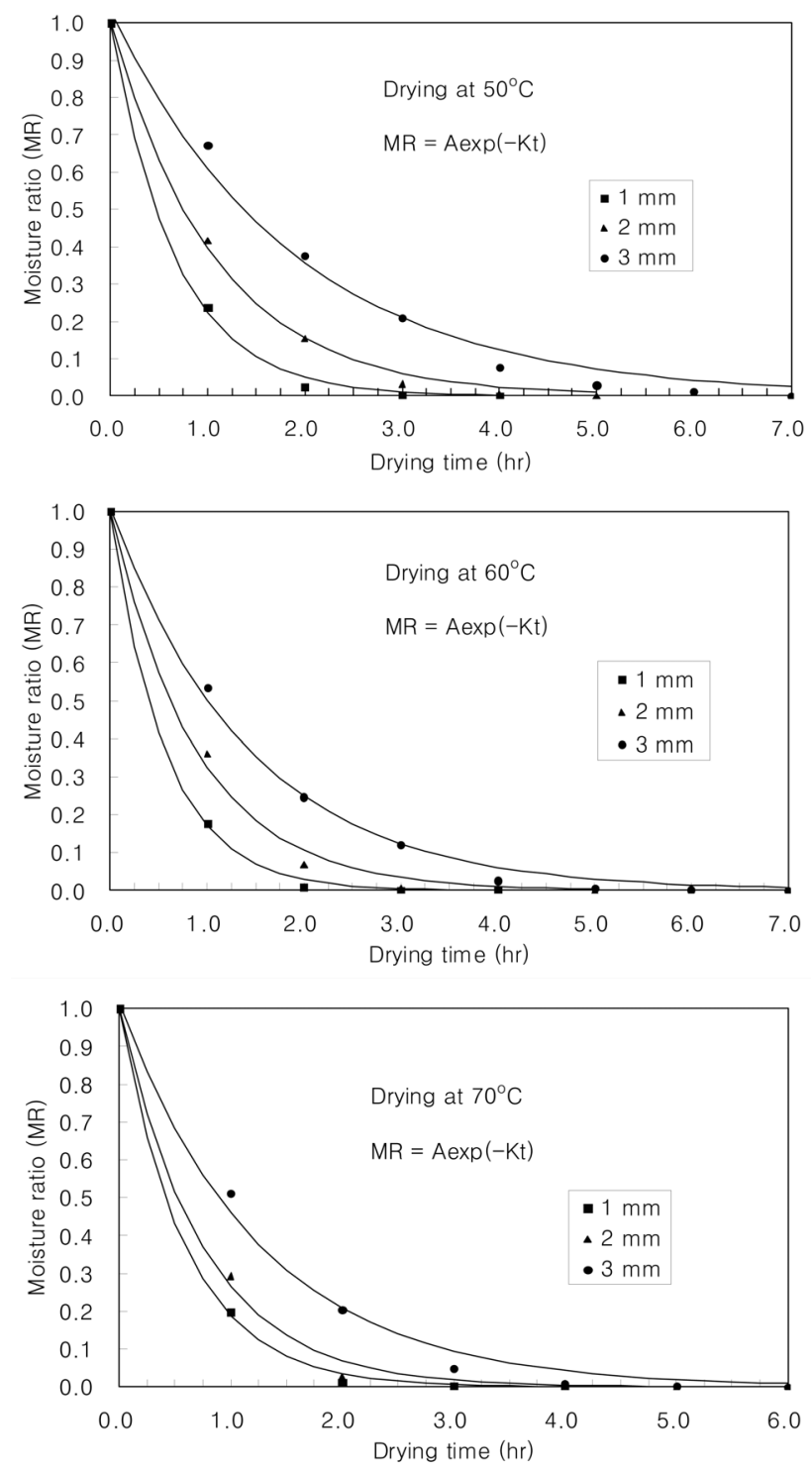

Figure 3. Drying curves of carrot. the drying temperature.

The effective diffusivity $\left(D_{\text {eff }}\right)$ was calculated by equation 4 for carrot and green pumpkin slices of 1,2 , and $3 \mathrm{~mm}$ thickness at drying temperature of $50^{\circ} \mathrm{C}, 60^{\circ} \mathrm{C}$, and $70^{\circ} \mathrm{C}$ (Table 2). The effective diffusivity was increased with increasing the drying temperature. The value of effective diffusivity was in the range of $3.38939 \times 10^{-7}$ to $4.77538 \times 10^{-7} \mathrm{~m}^{2} / \mathrm{hr}$ and $2.71069 \times 10^{-7}$ to $6.97618 \times 10^{-7}$ $\mathrm{m}^{2} / \mathrm{hr}$ for each carrot and green pumpkin slice.

The effective diffusivity $\left(D_{e f f}\right)$ is presented by Arrhenius equation of equation 5 . The relationship between $\ln \left(D_{\text {eff }}\right)$ and $1 / T$ has the linear relationship as taking natural logarithm on both sides of equation 5 . Figure 5 presents the linear relationships between $\ln \left(D_{\text {eff }}\right)$ and $1 / T$ in the
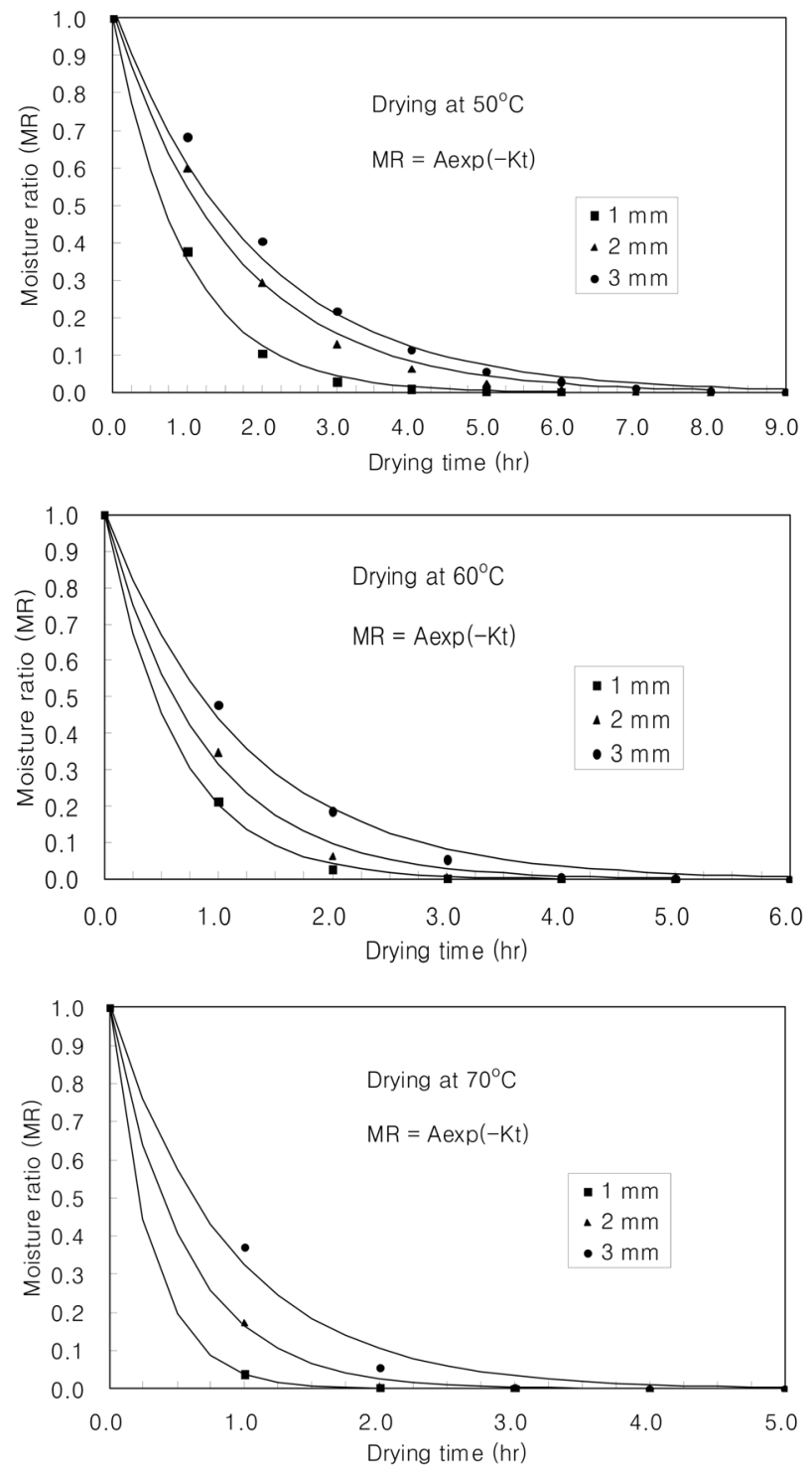

Figure 4. Drying curves of green pumpkin. 
Table 2. Values of $A, K, D$, and $r^{2}$ according to experimental conditions

\begin{tabular}{|c|c|c|c|c|c|c|}
\hline $\begin{array}{l}\text { Experimental } \\
\text { material }\end{array}$ & $\begin{array}{c}\text { Drying } \\
\text { temperature }\left({ }^{\circ} \mathrm{C}\right)\end{array}$ & $\begin{array}{l}\text { Thickness } \\
(\mathrm{mm})\end{array}$ & $A$ & $\begin{array}{c}K \\
\left(\mathrm{hr}^{-1}\right)\end{array}$ & $\begin{array}{c}D_{\text {eff }} \\
\left(\mathrm{m}^{2} / \mathrm{hr}\right)\end{array}$ & $r^{2}$ \\
\hline \multirow{9}{*}{ Carrot } & \multirow{3}{*}{50} & 1 & 1.0015 & 1.5022 & & 0.9988 \\
\hline & & 2 & 1.0055 & 0.9347 & $3.38939 \times 10^{-7}$ & 0.9977 \\
\hline & & 3 & 1.0335 & 0.5316 & & 0.9878 \\
\hline & \multirow{3}{*}{60} & 1 & 1.0006 & 1.7682 & & 0.9994 \\
\hline & & 2 & 1.0062 & 1.1290 & $4.2572 \times 10^{-7}$ & 0.9955 \\
\hline & & 3 & 1.0122 & 0.7009 & & 0.9962 \\
\hline & \multirow{3}{*}{70} & 1 & 1.0009 & 1.6738 & & 0.9991 \\
\hline & & 2 & 1.0038 & 1.3308 & $4.77538 \times 10^{-7}$ & 0.9961 \\
\hline & & 3 & 1.0157 & 0.7920 & & 0.9923 \\
\hline \multirow{9}{*}{ Green Pumpkin } & \multirow{3}{*}{50} & 1 & 1.0044 & 1.0415 & & 0.9985 \\
\hline & & 2 & 1.0205 & 0.6245 & $2.71069 \times 10^{-7}$ & 0.9946 \\
\hline & & 3 & 1.0308 & 0.4976 & & 0.9929 \\
\hline & \multirow{3}{*}{60} & 1 & 1.0007 & 1.5816 & & 0.9996 \\
\hline & & 2 & 1.0055 & 1.1601 & $4.62291 \times 10^{-7}$ & 0.9959 \\
\hline & & 3 & 1.0107 & 0.8280 & & 0.9958 \\
\hline & \multirow{3}{*}{70} & 1 & 1.0000 & 3.2551 & & 1.0000 \\
\hline & & 2 & 1.0007 & 1.8051 & $6.97618 \times 10^{-7}$ & 0.9992 \\
\hline & & 3 & 1.0078 & 1.1288 & & 0.9929 \\
\hline
\end{tabular}
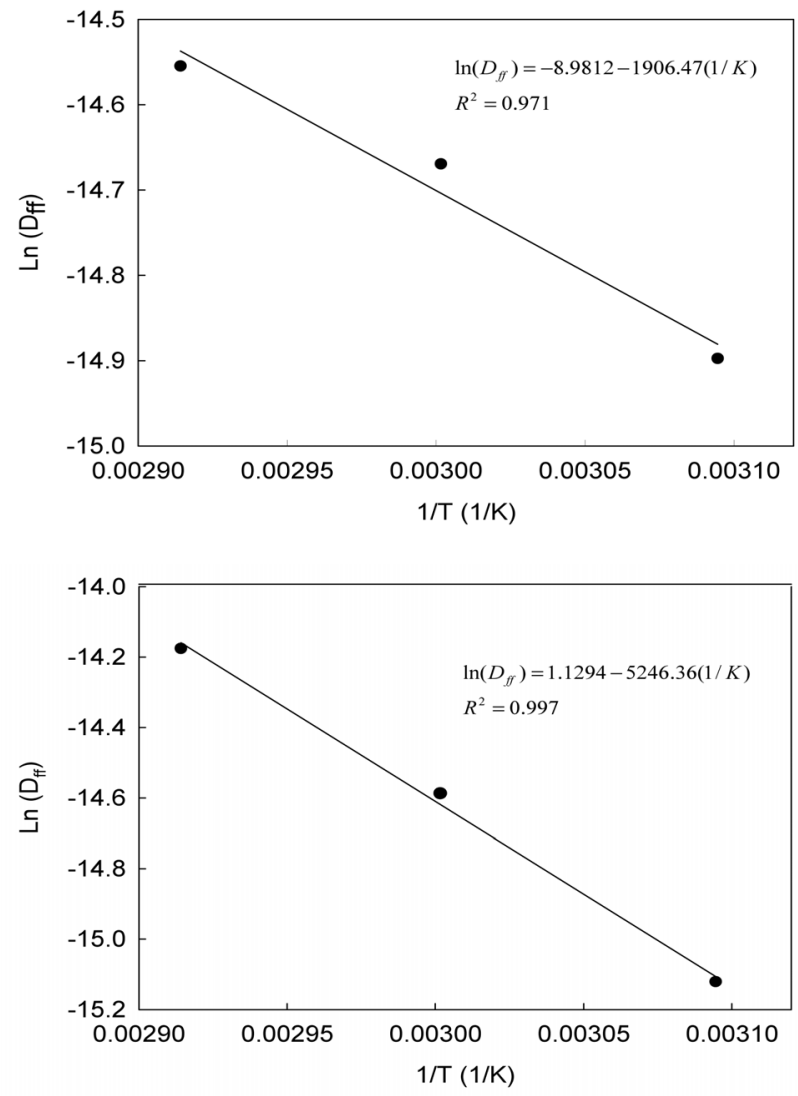

Figure 5. Relationship between drying temperature and effective diffusivity for carrot and green pumpkin. range of drying temperatures investigated for carrot and green pumpkin indicating Arrhenius dependence with the determination coefficients $\left(r^{2}\right)$ of $>0.97$.

\section{Conclusions}

In this study, thin-layer drying characteristics of carrot and green pumpkin slices were investigated, and mathematical models for the drying curves were developed during hot-air drying by waste heat dryer. The results showed that the drying time was decreased greatly with decreasing the slice thickness and increasing the drying temperature. The slop of drying curves implying the degree of drying rate was increased with increasing the drying temperature and decreasing the slice thickness. Theoretical models fitted to drying data for the drying curves had high value of determination coefficients $\left(r^{2}\right)$ of $>0.99$. Thus, it showed good exponential relationship between moisture ratio and drying time. In the drying model, the value of $K$ was decreased and the value of $A$ was increased with increasing the slice thickness and decreasing the drying temperature. The effective diffusivity $\left(D_{\text {eff }}\right)$ was increased with increasing the drying temperature. The value of effective diffusivity was in the range of 
$3.38939 \times 10^{-7}$ to $4.77538 \times 10^{-7} \mathrm{~m}^{2} / \mathrm{hr}$ and $2.71069 \times 10^{-7}$ to $6.97618 \times 10^{-7} \mathrm{~m}^{2} / \mathrm{hr}$ for each carrot and green pumpkin slice. The linear relationships between $\ln \left(D_{\text {eff }}\right)$ and $1 / T$ for carrot and green pumpkin showed well Arrhenius dependence with the determination coefficients $\left(r^{2}\right)$ of $>0.97$.

\section{Conflict of Interest}

No potential conflict of interest relevant to this article was reported.

\section{Acknowledgement}

This study was carried out with the support of 'Forest Science \& Technology Projects (Project No. S120910L070120)' provided by Korea Forest Service.

\section{References}

Abe, T. and T. M. Afzal. 1997. Thin-layer infrared radiation drying of rough rice. Journal of Agricultural Engineering Research 67:289-297.

Adu, B. and L. Otten. 1996. Diffusion characteristics of white beans during microwave drying. Journal of Agricultural Engineering Research 64:61-70.

Afzal, T. M. and T. Abe. 2000. Simulation of moisture changes in barley during far infrared radiation drying. Computers and Electronics in Agriculture 26:137-145.

Chinnan, M. S. 1984. Evaluation of selected mathematical models for describing thin-layer drying of in-shell pecans. Transactions of the ASAE 27(2):610-615.

Coumans, W. J. 2000. Models for drying kinetics based on drying curves of slabs. Chemical Engineering and Processing 39:53-68.

Crank, J. 1975. The Mathematics of Diffusion. 2nd ed. Oxford, UK: Clarendon Press.

Doymaz, I. and M. Pala. 2002. Hot-air drying characteristics of red pepper. Journal of Food Engineering 55(4): 331-335.

Duc, L. A., S. J. Hong, J. W. Han and D. H. Keum. 2008. Estimation of effective moisture diffusivity of rapeseed (Brassica napus L.). Journal of Biosystems Engineering 33(5):296-302.
Ekechukwu, O. V. 1999. Review of solar-energy drying system I: an overview of drying principles and theory. Energy Conversion and Management 40:593-613.

$\mathrm{Fu}, \mathrm{W}$. and W. Lien. 1998. Optimization of far infrared heat dehydration of shrimp using RSM. Journal of Food Science 63(1):80-83.

Henderson, J. M. and S. M. Henderson. 1968. A computational procedure for deep-bed drying analysis. Journal of Agricultural Engineering Research 13(2):87-95.

Henderson, S. M. and S. Pabis. 1961. Grain drying theory: I. Temperature effects on drying coefficient. Journal of Agricultural Engineering Research 6(3):169-174.

Henderson, S. M. and R. L. Perry. 1976. Agricultural Process Engineering. Westport, CT: AVI Publishing Co.

Kim, H. and J. W. Han. 2009. Low temperature drying simulation of rough rice. Journal of Biosystems Engineering 34(5):351-357 (In Korean, with English abstract).

Lee, G. H, W. S. Kang and F. Hsieh. 2004. Thin-layer drying characteristics of chicory root slices. Transactions of the ASAE 47(5):619-1624.

Lee, G. and F. Hsieh. 2008. Thin-layer drying kinetics of strawberry leather. Transactions of the ASAE 53(5): 1699-1705.

Madamba, P. S., R. H. Driscoll and K. A. Buckle. 1996. The thin-layer drying characteristics of garlic slices. Journal of Food Engineering 29(1):75-97.

Misra, M. K. and D. B. Brooker. 1980. Thin-layer drying and rewetting equations for shelled yellow corn. Transactions of the ASAE 23(5):1254-11260.

Osborn, G. S., G. M. White and L. R. Walton. 1991. Thinlayer moisture adsorption equation for soybeans. Transactions of the ASAE 34(1):201-206.

Pabis, S. and S. M. Henderson. 1961. Grain drying theory: II. Journal of Agricultural Engineering Research (4): 272-277.

Parry, J. L. 1985. Mathematical modeling and computer simulation of heat and mass transfer in agricultural grain drying: A review. Journal of Agricultural Engineering Research 32(1):1-29.

Ramesh, M. N., W. Wolf, D. Tevini and G. Jung. 2001. Influence of processing parameters on the drying of spice paprika. Journal of Food Engineering 49(1): 63-72.

Sarsavadia, P. N., R. L. Sawhney, D. R. Pangavhane and S. P. Singh. 1999. Drying behavior of brined onion slices. Journal of Food Engineering 40(3):219-226. 
Simal, S., A. Femenia, P. Llull and C. Rossello. 2000. Dehydration of aloe vera: simulation of drying curves and evaluation of functional properties. Journal of Food Engineering 43(2):109-114.

Tang, J. and S. Sokhansanj. 1993. Moisture diffusivity in laird lentil seed components. Transactions of the ASAE 36(6):1791-1798.

Weres, J. and D. S. Jayas. 1994. Thin-layer drying of corn: Experimental validation of a new numerical structural model. Canadian Agricultural Engineering 36(2):
85-91.

Youcef-Ali, S., H. Messaoudi, J. Y. Desmons, A. Abene and M. L. Ray. 2001. Determination of the average coefficient of internal moisture transfer during the drying of a thin bed of potato slices. Journal of Food Engineering 48(2):95-101.

Young, J. H. and T. B. Whitaker. 1971. Evaluation of the diffusion equation for describing thin-layer drying of peanuts in the hull. Transactions of the ASAE 14(2): 309-312. 